\title{
MULTICULTURALISME EDUCATION DALAM PENGUATAN PAHAM MODERASI DI PONDOK PESANTREN
}

\author{
Oleh : \\ Minhaji, Ilzam Dlaifi \& Luluk Maktumah \\ Universitas Ibrahimy Situbondo, Indonesia \\ minhaji@ibrahimy.ac.id, Ilzamdhaifi@gmail.com \& \\ luluadjie4@gmail.com
}

\begin{abstract}
:
Studies on multicultural education, in relation to strengthening the understanding of moderation in pesantren, are important, considering that Islamic education in various educational institutions has missed the substance of appreciating religious values and pluralist-multicultural religious practices. This phenomenon is very influential in the growth of an exclusive attitude and blind fanaticism, and even tends to be radical for students. The integralistic, humanist, tolerant and moderate education system in our country has actually existed for a long time in the Islamic boarding schools. Therefore, research on multicultural education in strengthening the understanding of moderation by taking the case that happened in Ma'had Aly Salafiyah Syafi'iyah Islamic Boarding School Situbondo is important. This research resulted in the findings that the application of multicultural education was carried out in two ways. First, the internalization of values, the additive level stage (addition) and the transformative level (change) stage. Second, the patterns of the dimension transformation value include: content integration (cultural integration); the knowladge construction process; an equality of pedagogment (adjustment of learning methods); culturally sensitive teaching strategies; (interaction in teaching); and prejudice reduction in instructional.
\end{abstract}

Keywords: Multiculturalisme Education, Moderasi, Pesantren

\section{A. Pendahuluan}

Asas pendidikan secara umum adalah diselenggarakan secara moderat, toleran, egaliter, dimokratis, bersifat manusiawi dan menghargai hak-hak peserta didik. Baik itu dilihat dari segi kultur, etnis, maupun paham keagamaannya. Kepentingan peserta didik tidak boleh terkalahkan oleh kepentingan lainnya. Asas tersebut manjadi dasar dan prinsip dalam sistem pendidikan nasioanal. Undang-Undang RI Nomor : 20 tahun 2003 khususnya Pasal 4 ayat (1) menyebutkan bahwa: pendidikan 
diselenggarakan secara demokratis dan berkeadilan serta tidak diskriminatif dengan menjunjung tinggi hak asasi manusia, nilai keagamaan, nilai kultur, dan kemajemukan bangsa.

Dalam artikel United Nation of Human Right Council (UNHRC) pasal 26 ayat (2) disebutkan; pendidikan harus diarahkan untuk sepenuhnya kepribadian seseorang sebagai manusia dan untuk memperkokoh dihargainya hak-hak manusia dan kebebasan-kebebasan dasarnya. Nilai edukatif yang dapat diambil dari statemen tersebut adalah pendidikan harus mampu menanamkan nilai toleransi, saling pengertian, moderasi serta persahabatan antar bangsa. Dengan demikian, setiap individu merasa mendapatkan penghargaan dan bertanggungjawab untuk membina kehidupan dengan komunitasnya. Pengingkaran suatu masyarakat akan pengakuan oleh masyarakat lainnya, adalah akar ketimpangan dari berbagai bidang kehidupan ${ }^{1}$. Disinilah pentingnya multikulturalisme diterapakan dalam proses pendidikan. Dengan pendidikan multikultural, diharapkan akan tumbuh nilai-nilai budaya pengakuan terhadap martabat manusia dalam komunitasnya dengan keunikan budaya masing-masing.

Dalam pespektif pendidikan Islam, pendidikan multikultural tidak bisa lepas dari konsep pluralis-moderasi. Dari sinilah kemudian mendorong lahirnya konsep pendidikan Islam pluralis-multikultural, sebuah konstruksi pendidikan yang berorientasi pada proses kesadaran sikap plural berwawasan multikultural. Pendidikan Islam dengan paradigma pluralis-multikultural tersebut dapat dikatakan sebagai bagian dari upaya sistematis dan komprehenshif dalam mencegah dan mengantisipasi tejadinya gesekan yang mengarah pada konflik beragama, radikalisme beragama, sparatisme dan ancaman disintegrasi bangsa. Nilai dasarnya adalah toleransi dan moderasi.

Undang-undang Nomor 20 tahun 2003, sebagai regulasi yang mengatur tata kelola sistem pendidikan di Indonesia, membagi pelaksanaan pendidikan Islam melalui dua jalur satuan lembaga pendidikan. Pendiikan Agama Islam, sebagai mata pelajaran pada sekolah umum dan Pendidikan Keagamaan pada satuan pendidikan bercirikan Islam, seperti madrasah dan pondok pesantren. Pendidikan Islam pada lembaga pendidikan "umum" maupun pendidikan keagamaan, memiliki muatan materi yang sarat dengan niali-nilai moralis-religius, dan pluralismultikultural. Namun faktanya, belum memberikan "kontribusi" yang memadai terhadap implementasi praktek keagamaan pada peserta didik.

1 Mahfud, C. Pendidikan Multikultura. (Yogyakarta: Pustaka Belajar, 2009), 164. 
Pendidikan Agama Islam seolah-olah hanya menyentuh aspek kognitif semata, belum sampai pada ranah afektif, apalagi psikomotorik. Peserta didik sekedar tahu dan hafal saja terhadap materi agama melalui transfer pengetahuan dari guru sesuai dengan kurikulum yang ada, sedangkan pada substansi penghayatan nilai keagamaan seolah-olah terlupakan dan menjadi sesuatu yang kurang penting.

Dengan meningkatnya pengetahuan agama yang tidak diimbangi oleh penghayatan, praktik nilai-nalai keagamaan pluralis-multikultural dan sentuhan sikap humanis dan kepedulian sosial, maka berkonsekuensi terhadap tumbuhnya prilaku atau sikap ekslusif dan fanatisme buta, bahkan cenderung "radikal" bagi anak didik. Sikap demikian itu pada gilirannya kemudian menimbulkan perilaku intoleransi terhadap perbedaan keyakinan atau paham keagamaan serta sulit menerima terhadap keberagaman etnis maupun budaya. Oleh kerena itu, pendidikan Islam yang mengedepankan nilai-nilai humanis, moderat, dan toleran sangat dibutuhkan sebagai titik temu, "bukan titik tengkar" dalam kehidupan sosial keagmaan yang multikultural di Indonesia.

Sistem pendidikan yang molaris, humanis, toleran, moderat dan integralistik di Indonesia, sebenarnya telah ada sejak dulu, terutama di kalangan pendidikan pesantren. Pondok pesantren sebagai lembaga pendidikan asli (indegenous) Indonesia ${ }^{2}$ dan tertua karena keberadaannya bersamaan dengan masuknya Islam di Indonesia ${ }^{3}$, telah lama menerapkan konsep pendidikan multikultural. Nilai-nilai pendidikan multikultural yang dimaksudkan seperti kesetiakawanan, kebersamaan, kesederhanaan dan sikap toleran sesama santri. Mereka berbaur tidak "elitis" dan tidak membeda-bedakan antar teman yang sama-sama belajar di pesantren. Nilai-nilai tersebut diinternalisasikan ke dalam diri para santri melalui proses pemebelajaran, pengajian serta dicontohnya langsung oleh para kiai sebagai guru dan pemimpin pondok pesantren.

Pondok pesantren dengan berbagai cirikhasnya itu, selain menjalankan perannya sebagai lembaga pendidikan, lembaga dakwah, juga berperan sebagai lembaga sosial kemasyarakatan. Itulah sebabnya Abdurrahman Wahid menyebutnya sebagai subkultur dari kehidupan sosial masyarakat. Dalam berbagai studi tentang kependidikan, pondok

2 Madjid, Nurcholish, Bilik-Bilik Pesantren: Sebuah Potret Perjalanan, (Jakarta: Paramadina, 1997), 3.

3 Mastuhu. Dinamika Sistem Pendidikan Pesanantren, Suatu Kajian tentang Unsur dan Nilai Sistem Pendidikan Pesantren, (Jakarta: INIS, 1994), 19. 
pesantren selalu menjadi objek kajian yang menarik untuk diperbincangnkan secara akademis. Baik dilihat dari model pembelajarannya, paham ritual keagamaanya, maupun manajemen pengelolaannya. Kajian ini secara spesifik dititik beratkan pada penerapan pendidikan multikultural, kaitannya dengan paham moderasi (wasthiyah) sebagai cirikhas paham ritual keagamaan yang diajarkan di pesantren.

Salah satu pondok pesantren yang menarik untuk dilakukan kajian adalah PP Salafiyah Syafi'iyah yang selanjutnya disebut PPSS Sukorejo Situbondo dalam mengelola Ma'had Aly. Ma'had Aly PPSS. Situbondo ini didirikan oleh KHR. As'ad Syamsul Arifin pada tahun 1990. Tahun 2017 diresmikan oleh Menteri Agama RI menjadi Perguruan Tinggi Pesantren pertama dibawah naungan Kemenag RI. Hal menarik yang sekaligus menjadi bahan kajian dalam penelitian ini adalah Ma'had Aly PPSS Situbondo dengan spesialisasi usul fiqih-nya, mampu menampilkan corak pemahaman keagamaan yang moderat (wasathiyah) dan humanis. Nilainilai pendidikan multikultural diinternalisasikan kedalam sistem pembelajaran berbasis multi madzhab yang dikaji secara akademik, namun nilai-nilai luhur pesantren tetap terjaga dan terpelihara dengan baik. Doktrin Ahlussunnah Waljama'ah al-Nahdliyah sebagai landasan sikap sosial keagamaan senantiasa menjadi pedoman dalam proses interaksi edukatif di kelas maupun di luar kelas.

Berdasarkan data-data awal di atas, konstruksi lemabaga Pendidikan Ma'had Aly dengan sentuhan multikulturalisme-nya dilihat dari faham sosial keagamaannya, tentu menjadi tantangan dan keunikan tersendiri bagi aktor pengelola pondok pesantren. Apalagi jika dihadapkan dengan menjamurnya faham ekstrimis-radikalis yang cenderung monokulturalisme akhir-akhir ini. Dengan kata lain, kajian pembelajaran fiqih multi-madzhab yang diterapkan Ma'had Aly PPSS, setidaknya menjadi conter naratif terhadap berkembangnya pengaruh transnasional sebagian golongan yang mengembangkan paham "radikalisme" dalam praktik keagamaan. Atas dasar argumentasi itulah maka kajian tentang penerapan multiculturalisme education dalam penguatan paham moderasi di podok pesantren ini perlu dilakukan.

Dalam rangka untuk mencari jawaban dari kegelisan akademik sebagaimana uraian di atas, maka kajian ini difokuskan pada : "Bagaimana penerapan pendidikan multikultural dalam penguatan paham moderasi di pondok pesantren, dengan mengambil kasus yang terjadi di Ma'had Aly PPSS Situbondo. Berangkat dari fokus tersebut, maka kajian ini kemudian memiliki tujuan untuk mendeskripsikan dan mengeksplorasi tentang penerapan pendidikan multikultural dalam 
penguatan paham moderasi yang terjadi di pondok pesantren tersebut.

\section{B. Krangka Konseptual Pendidikan Multikultural}

Pendidikan multikultural (multikulturalisme education) secara etimologis berasal dari dua kata, yaitu pendidikan dan multikultural. Kata pendidikan, dimaknai sebagai proses memanusiakan manusia. Yakni pengembangan sikap dan tingkah laku individu maupun kelompok manusia dalam upaya proses pendewasaan melalui pendidikan, pembimbingan, pengajaran maupun pelatihan. Sedangkan kata "multikultural" adalah manifestasi dari keragaman budaya yang melatarbelakangi kehidupan seseorang 4 . Adapun secara terminologis pengertian pendidikan multikultural dapat dikelompokkan menjadi dua definisi, yaitu : (a) definisi pendidikan multikultural yang dibangun melalui pendekatan prinsip-prinsip demokrasi, kesetaraan dan keadilan; (b) definisi yang terbangun melalui pendekatan sikap sosial, yaitu: penghargaan, pengakuan dan penerimaan.

Dari dua pendekatan tersebut, pendidikan multikultural diharapkan dapat mengantarkan manusia Indonesia berjiwa nasionalis, sehingga pada gilirannya kemudian mampu mempertahankan keutuhan bangsa dari ancaman disintegrasi. Apabila penerapannya dipadukan dengan pendekatan religius-etik (keagamaan), maka pendidikan multikultural itu mampu mengantarkan anak didik memiliki paham yang moderat dan inklusif. Terciptanya budaya peradaban yang demikian itu, adalah merupakan sutau hal yang sangat penting bagi pengembangan pendidikan di Indonesia dengan kondisi penduduknya yang multi etnik, multi-agama dan plural. Sejalan dengan itu, menururt Mahfud terminologi pendidikan multikultural mengandung makna pengakuan terhadap keunikan komunitas budaya masing-masing individu sebagai wujud penghargaan akan harkat dan martabat seseorang. Masing-masing merasa dihormati dan dihargai, sehingga tumbuh perasaan tanggung jawab untuk membina kehidupan bersama komunitasnya. Asumsi dasarnya adalah mengingkari terhadap kebutuhan masyarakat akan pengakuan oleh komunitas lainnya adalah merupakan akar ketimpangan dari berbagai sektor kehidupan di masyarakat ${ }^{5}$.

Jika demikian pengertiannya, maka pendidikan multkultural memiliki indikasi bukan sekedar bahan kajian secara akademik semata, melainkan perlu adanya usaha yang simultan untuk memperjuangkan

${ }^{4}$ Ainurrofiq, D. "Emoh" Sekolah Menolak "Komersialisasi Pendidikan" dan "Kanibalisme Intelektual”, Menuju Pendidikan Multikultural, (Yogyakarta: INSPEAL Press, 2003), 100.

5Mahfud, C. Pendidikan Multikultura. (Yogyakarta: Pustaka Belajar, 2009), 75

$$
\text { JURNAL LISAN AL-HAL } \mid 283
$$


keadilan sosial serta memberikan kesempatan yang sama terhadap berbagai pihak dalam kehidupan sosisal. Bennet C meletakkan sikap humanis, plural, keadilan sosial, moderasi sebagai prinsip utama konsepsi pendidikan multikultural demi pencapaian tujuan masingmasing peserta didik. Argumentasi Bennet didasrkan pada peserta didik memiliki tujuan atau hasrat untuk ikut ambil bagian dan menyatu dengan orang lain dalam berbagai aktifitas di masyarakat, bahkan dengan alam sekitarnya.

Dengan demikian, pendidikan multikultural selanjutnya diharapkan mampu melahirkan peserta didik memiliki pandangan humanis-moderasi, sehingga bisa menjalankan kehidupan tanpa membeda-bedakan kelompoknya, seperti perbedaan etnis, gender, budaya, ras, agama dan stratifikasi sosial di masyarakat ${ }^{6}$. Dalam perspektif keagamaan, orientasinya adalah memaksimalkan berkembangnya konpetensi dan potensi peserta didik sesuai kodratnya yang merupakan anugrah dari Allah Swt.

Argumentasi di atas memberikan pemahaman bahwa dalam kehidupan suatu bangsa yang plural dan majmuk adalah dipenuhi dengan budaya-budaya yang beragam. Tesis ini sejalan dengan pendapat Ngainun Naim, ia mengatakan nilai dasar dari pendidikan multikultural adalah toleransi dan moderasi. Dalam perspektif pendidikan Islam dikenal dengan konsep pluralis. Dari konsep pluralisme inilah kemudian muncul istilah Pendidikan Islam pluralis-multikultural, berorientasi pada proses kesadaran berwawasan plural dalam beragama dan multikultural dalam berbudaya.

Kandungan nilai pendidikan multikultural menurut Tilaar dapat dibagi menjadi empat nilai (core values) ${ }^{7}$, yaitu; (a) nilai apresiatif; yaitu diwujudkan dalam bentuk penghargaan terhadap pluralitas budaya sebagai kenyataan hidup di masyarakat; (b) nilai pengakuan terhadap hak asasi manusia sebagai wujud dari penghargaan akan harkat dan martabat manusia itu sendiri; (c) nilai tanggungjawab manuisia sebagai bagian dari masyarakat global, dan; (d) nilai tanggung jawab manusia akan kelestarian lingkungan alam semesta.

\section{Acuan Studi Pendidikan Multikultural}

6 Ibid, 177.

7 Tilaar, H.A.R. Perubahan Sosial dan Pendidikan: Pengantar Pedagogik Transformatif untuk Indonesia, Jakarta: Grasindo, 2004.

$284 \mid$ JURNAL LISAN AL-HAL 
Kajian tantang pendidikan multikultural ini cukup banyak yang dilakukan oleh para peneliti dengan berbagai perspektif masing-masing. Antara lain adalah Paulo Freire. Sebagai tokoh pendidikan yang sangat berpengaruh pada abad ke-20, Freire dalam sebuah karyanya, menuliskan pernyataan yang cukup menarik untuk dipelajari. Pernyataan tersebut yaitu pendidikan bukan sebuah "menara gading" yang jauh dari realitas sosial dan kultur budaya masyarakat. Lebih lanjut Freire menegaskan, bahwa esensi proses pendidikan yang sebenarnya adalah terciptanya tatanan masyarakat terdidik, bukan masyarakat yang mengagungkan pristise sosial karena harta dan kekayaan semata.. Pendapat ini memberikan pemahaman, bahwasanya pendidikan multikultural itu mendidik bagaimana cara merespon perubahan sosial demografis kultur mayarakat tertentu, bahkan dunia sekalipun melalui keragaman budaya.

Tesis yang diajukan oleh Freire ini sejalan dengan hasil temuan Cooper Hilliard. Dalam pandangan Hilliard pendidikan multikultural adalah sebagai respon terhadap berkembangnya keragaman populasi lembaga pendidikan. Oleh karena itu, proses pendidikan menuntut perlakuan persamaan hak bagi setiap kelompok. Selain itu, juga sebagai pengembang kurikulum dan aktifitas pembelajaran yang berrtujuan mengakomudir berbagai pandangan serta memberikan perhatian bagi orang-orang etnis tertentu, terutama dari kelompok menoritas.

Selain dua penelitian tersebutr di atas, salah satu penelitian yang dilakukan oleh peneliti insider juga patut dijadikan acuan, yaitu hasil penelitian yang dilakukan H.A.R. Tilaar. Menurut Tilaar, konsen pendidikan multikultural adalah berkaitan dengan pengembangan sikap dan tingkah laku masingmasing individu maupun kelompok. Di dalamnya terdapat unsur pendewasaan individu (manusia) melalui pendidikan, pengajaran, pelatihan dan proses pembimbingan. Semua itu dilakukan dengan secara humanistik, menghargai pluralitas dan heterogenitas. Pendidikan multikultural ini juga dapat dipahami sebagai sebuah tawaran konsep untuk proses pengembangan pendidikan di Indonesia kedepan, khususnya pendidikan yang bercirikan Islam seperti pondok pesantren, madrasah dan lain sebagainya. (Tilaar, 2004; 27). Hal ini sejalan dengan pendapat Howard yang menegaskan konstruksi pendidikan itu esensinya adalah guru membantu murid untuk memahami bagaimana pengetahuan diperoleh dan membangun kepribadian, sehingga memberikan pengaruh terhadap posisi sosial murid secara individu maupun kelompok. ${ }^{8}$

8 Tilaar, H.A.R. Perubahan Sosial dan Pendidikan: Pengantar Pedagogik Transformatif untuk Indonesia, (Jakarta: Grasindo, 2004), 261-267. 
Selain beberapa penelitian terdahulu di atas, salah satu acuan utama dalam kajian ini adalah hasil penelitian James Bnks yang membahas mengenai pendidikan multikultural. Dalam penelitiannya, Banks membagi lima dimensi pendidikan multikultural, yaitu :

a. Interations of Conten in Instructional; yaitu mengintegrasikan berbagai kelompok budaya. Di sini terjadi proses ilustrasi konsep yang mendasar atau teori-teori yang bersifat umum baik itu dalam kurikulum maupun sebaran pada mata pelajaran salah satu disiplin ilmu pengetahuan ;

b. The Knowladge Construction Process in Instructional; yaitu memberikan pemahaman terhadap peserta didik tentang implikasi budaya. Pemahaman tersebut dikonstruksi dalam sebuah mata pelajaran atau salah satu disiplim keilmuan tertentu;

c. An Equity Paedagogy in Instructional; yaitu penyesuaian metode pembelajaran dengan kebiasaan dan gaya belajar anak didik. Hal ini dimaksudkan untuk menfasilitasi keragaman prestasi akademik yang mereka miliki. Keragaman itu baik dilihat dari segi ras, budaya, maupun segi strata sosialnya;

d. Trainning Participation in Instructional; yaitu melatih peserta didik berpartisipasi dalam berbagai kegiatan. Dengan demikian, meraka diharapkan mampu berinteraksi dengan komunitas etnis mapun ras yang berbeda. Hal itu dimaksudkan dalam rangka untuk mewujudkan terciptanya kultur akademik yang harmonis;

e. Prejudice Reduction ini Intractiona, yaitu mengidentifikasi karakteristik peserta didik dilihat dari segi ras maupun etniknya. Dari identifikasi tersebut kemudian menetapkan metode pembelajaran apa yang pas untuk mereka9.

Kerangka konseptual yang dikemukakan James Bank tersebut di atas adalah menjadi tool of analisys dalam penelitian ini. Teori tersebut kemudian didiskusikan dengan fakta-fakta empirik yang ditemukan di lapangan berupa proposisi-proposisi, sehingga kemudian terbangun krangka konseptual sebagai bangunan teori baru dalam penelitian ini. Adapun dimensi pendidikan multikultural oleh Banks tersebut selanjutnya dapat disajikan dalam bentuk tabel berikut ini:

Tabel Dimensi Pendidikan Multikultural

\begin{tabular}{lll}
\hline No & Dimensi & Instruksi \\
\hline 01 & Content integrations & Integrasi budaya
\end{tabular}

${ }^{9}$ Banks, J.A. An introduction to Multicultural Education, (Boston-London: Allyn and Bacon Press, 2004), 199.

$286 \mid$ JURNAL LISAN AL-HAL 


\section{The Knowladge Construction Process}

03 An Equity Paedagogy

04 Trainning participation

05 Prejudice Reduction
Konstruksi budaya

dalam

pengetahuan

Metode pengajaran

Interaksi dalam

pengajaran

Identifikasi karakter

Sumber: James Bank (2004)

\section{Internalisasi Nilai Pendidikan Multikultural di Pondok Pesantren}

Nurcholish Madjid dalam beberapa kajiannya tentang pesantren menjastifikasi pesantren sebagai lembaga pendidikan asli (indigenous) Indonesia yang memiliki karakter dan ciri yang khas dalam model pendidikannya. Ciri khas tersebut setidaknya dapat dilihat dari aspek transmisi dan internalisasi nilainya dan penguasaan serta pemahaman keagamaannya. Ciri khas utama pesantren adalah terletak pada kitab kuning dan model pembelajaran bandongan dan sorogan yang dijalankannya. Beberapa cirikhas inilah kemudian menjadi pembeda dengan institusi pendidikan lainnya di luar pesantren. Meskipun sebagian besar pesantren saat ini sudah bertransformasi ke dalam model pendidikan modern, akan tetapi stereotipe "tradisional" itu masih tetap melekat pada institusi pendidikan bernama pesantren itu.

Hal menarik lainnya yang layak menjadi bahan kajian dalam pendidikan pondok pesantren adalah tentang penenerapan pendidikan multikultural. Dari data-data yang peneliti raih di lapangan, telah tergambar bahwa terjadi proses internalisasi nilai pendidikan multikultural melalui proses interaksi edukatif yang terprogram melalui desain pemebelajaran berbasis tradisi pesantren di Ma'had Aly PPSS Sukorejo Situbondo. Proses internalisasi nilai-nilai pendidikan multikultural tersebut menurut Asmuki secara garis besarnya dapat dibagi menjadi dua bagian, yaitu: (1). Aktifitas kegiatannya didesain oleh lembaga; yaitu seluruh proses interaksi edukatif ditangani langsung oleh lembaga (manajemen) Ma'had Aly. Hal ini meliputi penentuan Standar Kompetensi Lulusan, desain kurikulum, proses pembelajaran maupun sistem evaluasinya. Semua itu dilakukan dengan pendekatan total institution, yakni dengan cara menintegrasikan aktifitas pembelajaran dengan kegiatan pondok pesantren; (2). Kegiatan interaksi edukatif yang didesain oleh Mahasantri Ma'had Aly; kegiatan ini lebih mengarah pada fokus kajian tentang sosial keagamaan, baik yang bersifat klasik maupun kontemporer dengan pendekatan multi madzhab. Hasil kajian tersebut kemudian dipublikasikan melalui wadah lembaga penerbitan yang 
juga digagas oleh Mahasantri Ma'had Aly sendiri, seperti "Tanwirul Afkar" dan lain sebagainya. Melalui Tanwirul Afkar inilah karya-karya Mahasantri Ma'had Aly bisa diakses oleh berbagai kalangan sebagai pengembangan hazanah keilmuan. Publikasi ilmiah yang dihasilkan dalam bentuk majalah mingguan, jurnal karya ilmiah maupun buku-buku yang terbit secara online (daring) dan ofline (cetakan).

Proses internalisasi nilai pendidikan multikultural tersebut, jika mengacu pada pendapat James Banks , maka telah terjadi proses internalisasi nilai-nilai pendidikan multikultural pada materi pelajaran yang dilakukan dengan mengintegrasikan nilai budaya multikultural kedalam kurikulum, perencanaan serta proses pembelajaran. Dalam perspektif Banks, ada dua tahap yang dapat dilakukan oleh lemabaga pendidikan termasuk institusi pondok pesantren dalam melakukan internalisasi nilai-nilai pendidikan multikultural, yaitu :

\section{Tahap Penambahan (Additive Level)}

Pada tahap penambahan ini, perencanaan pembelajaran atau kurikulum dilakukan dengan cara menambahkan nilai-nilai dan konsep multikulturalisme kedalam kurikulum yang sudah ada. Dilakukan dengan cara memberikan tambahan pemahaman mendasar terhadap para mahasantri, meskipun pada prinsipnya nilai-nilai tersebut adalah merupakan tradisi yang biasa dilakukan di kalangan pendidikan pondok pesantren. Ada tiga kata kunci utama yang menjadi catatan dalam tahap penambahan (additive level) ini, yaitu ; pengembangan, perbaikan dan penyaringan. Dengan demikian, tahap penambahan ini berdampak pada berkembangnya potensi mahasantri untuk berprilaku yang baik serta memiliki pemahaman wawasan keilmuan yang luas (moderat), namun tetap berpedoman pada karakter dan budaya khas pesantren.

Dalam kasus Ma'had Aly PPSS tahap additive level ini sangat efektif dalam melakukan penanaman nilai-nilai tradisi khas, karena Mahasantri melakukan enkulturasi penuh selama 24 jam. Mahasantri melakukan aktifitas dan berada di pesantren sepanjang hari dengan ful aktifitas baik yang diprogram oleh lembaga maupun yang didesain oleh Mahasantri sendiri. Beberapa alasan lain yang juga penting untuk diutarakan terutama dalam membangun paham moderasi di Ma'had Aly PPSS antara lain adalah :

a. Pola internalisasi nilai-nilai moderasi di pondok pesantren ini sangat di pengaruhi oleh nilai-nilai ahlu al-Sunah wa al-Jamaah al-Nahdliyah. Prinsipprinsip tawassut, tasamuh dan ta'adul senantiasa ditanamkan dalam berbagai aktifitas interaksi edukatif yang dilaksanakan di kelas maupun di luar kelas; 
b. Penguasaan ilmu alat/metode menjadi kunci untuk memahami kita-kitab turath sebagai referensi primer kajian keislaman. Hal ini berangkat dari kesadaran secara akademik bahwa pemahaman terhadap ajaran agama yang sumber utamanya al-Qur'an dan al-Sunnah adalah tidak akan memadai, tanpa diimbangi dengan penguasaan metodologis yang cukup. Bahkan pada tingkat selanjutnya proses pembelajaran fiqhi/ushul fiqih sebagai konsentrasi diintegrasikan dengan disiplin keilmuan lainnya seperti al-Qur'an,Tafsir, Hadith, Balagah, Mantiq, Ma'ani dan lain sebagainya.

c. Respon terhadap perkembangan kajian Islam kontemporer dan sosial kemasyarakatan dilakukan melalui berbagai aktifitas kajian yang bersifat konprehenshif kritis-dialogis dan bertanggung jawab. Aktifitas tersebut seperti bathsul masaail, seminar, lokakarya, sidang redaksi majalah serta forum-forum ilmiah lainnya. Hal itu menjadikan proses internalisasi terhadap nilai-nilai pendidikan multikultura bersifat terbuka.

\section{Tahap Perubahan (Transformative Level)}

Pada tahap transformatif level ini, jika mengacu pada apa yang ditawarkan oleh Banks, maka Mahasantri dihadapkan dan dilatih pada sejumlah konsep dari berbagai perspektif. Hal itu meliputi perspektif etnik, ras, budaya maupun agama, semuanya dilakukan secara analisis kritis dan bertanggung jawab. Pada level ini, sangat diperlukan adanya asupan-asupan gagasan dari berbagai perspektif yang bersumber dari kekayaan referensi yang cukup memadai. Hal ini sejalan dengan penuturan Asmuki, bahwa pendidikan multikultural di Ma'had Aly PPSS Situbondo lebih mengarah pada transformasi paham keagamaan karena meskipun dalam retual keagaan sehari-hari bermadzhab Syafi'i, namun dalam studi keilmuan Mahasantri diajarkan dan terbiasa dengan referensi di luar madzhab Syafi'i. Pernyataan tersebut sejalan dengan temuan Abd. Muqith (2018) dalam sebuah disertasinya. Muqith mengistilahkan aktifitas pembelajaran di Ma'had Aly PPSS dengan terminologi Pendidikan Agama Islam berbasis multi madzhab. Istilah multi madzhab ini jika dikontekskan dengan pendapat Ngainun Naim, maka pemahaman sebuah ide dijelaskan dalam pola transformasi dimensi multikulturalisme education yang berorientasi pada proses penyadaran berwawasan pluralismoderat dalam paham keagamamaan dan multikultural secara budaya.

\section{E. Pola Transformasi Dimensi Pendidikan Multikultural di Pesantren}

Dalam frame teori pendidikan multikultural James Banks (2004), terdapat lima dimensi pendidikan multikultural yang dapat dilihat dalam

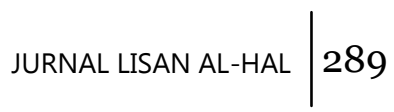


transformasi pendidikan pondok pesantren. Lima dimensi proses transformasi tersebut meliputi :

1. Conten Integration (integrasi budaya). Pada tahap dimensi ini proses transformasi dilakukan dengan cara mengadopsi beberapa contoh budaya untuk dikolaborasikan menjadi konsep-konsep, prinsip, generalisasi dan teori dalam suatu kajian. Mahasantri diajarkan pada sikap pengembangan budaya pesantren yang merupakan integrasi dari pengembangan sikap saling menghargai, pengendalian diri, tolong menolong dan kebersamaan dalam kegiatan sosial kemasyarakatan melalui kerja sama yang saling menguntungkan. Juga prasangka sosial yang berkembang dalam suatu kelompok keagamaan terhadap kelompok keagamaan lainnya dapat diminimalisasi.

2. The Knowladge Construction Process (Konstruksi budaya dalam pengetahuan). Konstruksi interaksi edukatif yang dikembangkan tidak hanya penguasaan ilmu-ilmu keagamaan semata, melainkan juga menyangkut wawasan hidup dan prilaku Mahasantri. Sedangkan para kiai yang mengajarnya adalah lebih memiliki kesempurnaan wawasan dalam berbagai kehidupan. Disinilah terjadi proses transformasi moral diantara Mahasantri yang dilakukan oleh para kiai ${ }^{10}$. (Wahid, 2007 : 131). Telah dijelaskan bahwa proses internalisasi nilai pesantren di lakukan melalui pengamalan tradisi pesantren dalam kehidupan sehari hari. Proses pembelajaran yang dinikmati oleh mereka berlangsung secara lues, maskipun tentu terdapat beberapa aturan sebagai prosedur tatakelola secara kelembagaan. Proses seperti ini diharapkan dapat membantu Mahasantri memahami, menemukan, dan menentukan pola pikir yang terbuka dan egaliter.

3. An equality of Pedagogment (tahap metode pembelajaran). Sebagai salah satu Perguruan Tingggi Pesantren, Ma'had Aly PPSS tentu memiliki sistem pembelajaran yang khas. Sistem pembelajaran dengan karakteristik tersendiri, terutama tidak menganut ketentuan-ketentuan formalistik prosedural administratif semata, namun tetap dalam koredor norma-norma yang ada di Perguruan Tinggi Pesantren. Metode pembelajaran model sorogan, bandongan, wetonan dan setoran hafalan serta kitab-kitab kuning klasik sebagai referensi tetap dipertahankan. Namun demikian, proses pembelajarannya dijalankan dengan pendekatan aktif akseleratiflearning dan budaya dialogis dalam pengembangan kajian keilmuan.

4. Culturally Sensitive Teaching Strategies (tahap interaksi dalam pengajaran). Dalam tahap ini, dosen memberikan cara mengajar agar membantu capaian 2007), 131.

10 Gusdur A. Wahid, Menjawab Kegelisahan Rakyat, Jakarta: Penerbit Buku Kompas, $290 \mid$ JURNAL LISAN AL-HAL 
pembelajaran mahasantri dalam memahami pembelajaran di pesantren. Kegiatan yang dilaksanakan adalah menerapkan nilai-nilai kepesantrenan yang dilandasi oleh prinsip Ahlussunnah Waljamaah al-Nahdliyah. Model Kegiatan ini di tekankan pada aspek kognitif, afektif dan psikomotorik sebagai gabungan antara pengajaran berbasis kurikulum model pengalaman hidup dan pendidikan keterampilan bagi mahasantri.

5. Prejudice Reduction in Instructional; yaitu mengidentifikasi karakteristik peserta didik dengan memberdayakan struktur sosial dan budaya sosial lembaga pendidikan sebagai sistem sosial yang kompleks. Sebagai lembaga pendidikan yang inklusif, keberadaan Ma'had Aly PPSS juga tidak bisa dilepaskan dari pengaruh inovasi-inovasi baru yang berasal dari luar karena pesantren bukan merupakan institusi pendidikan yang jumud dan tidak berkembang. Akan tetapi juga akomudatif namun tetap selektif terhadap perubahan-perubahan yang terjadi seiring dengan perkembangan ilmu pengetahuan. Doktrin Ahlussunnah Waljama'ah an-Nahdliyah yang digunakan, merupakan metode pesantren dalam menghadapi dan merespon perubahan tersebut. Penerimaan terhadap hasil pengembangan keilmuan baru dengan tetap mempertahankan ajaranajaran lama yang masih relevan. Pengembangan khazanah keilmuan baru tersebut tidak serta merta diterima, prinsip memelihara nilai-nilai lama yang masih relevan, dan menerima inovasi baru yang lebih baik tetap dipertahankan. Dengan demikian pesantren bersifat terbuka terhadap perbedaan baik berupa inovasi maupun dalam hal keragaman ajaran dan pemikiran.

Penguatan paham keagamaan moderat (wasathiyah), humanis dan moralis-religius baik yang dilakukan melalui proses internalisasi nilai maupun pola transformasi dimensi nilai multikultural di Ma'had Aly PPSS telah mendapat pengakuan oleh masyarakat luas. Salah satunya adalah salah seorang Guru Besar Universitas al-Azhar Kairo Mesir, yaitu Ibrahim Sholeh Sayyid Sulaiman al Hud Hud. Dalam sebuah kesempatan, Hud-Hud memberikan pujian terhadap Ma'had Ay PPSS Sukorejo Situbondo. Menurutnya Ma'had Aly PPSS memiliki titik persamaan cirikhas keilmuan dengan al-Azhar Mesir. Kesamaan tersebut setidaknya dapat dilihat dari konsestensi Ma'had Aly PPSS dalam mengajarkan Islam moderasi (wasathiyah), kemulyaan akhlak dan budi pekerti yang baik sejak berdirinya hingga sekarang11.

Penilaian tersebut cukup beralasan karena jika dikaji lebih jauh

11 https://www.harianbhirawa.co-.id/ppss-sukorejo-universitas-al-azharsepakati-lima-keilmuan-internasional/ 
berkesesuaian dengan pendapat Donna M. Gollnick yang mengatakan bahwa; dalam kehidupan sosial kemasyarakatan yang bersifat majmuk, diperlukan adanya sikap saling menghargai, mengakui serta menerima adanya perbedaan maupun keragaman. Lebih lanjut Gollnik mengatakan; sikap mengakui, menerima dan menghargai terhadap perbedaan maupun keragaman adalah laksana sebuah mozaik dalam kehidupan masyarakat. Cakupan dari mozaik tersebut meliputi semua aspek budaya di masyarakat mulai yang lebih kecil, lalu kemudian melahirkan bentuk budaya masyarakat yang lebih besar'12.

Islam sebagai agama yang rahmatan lilalamin, lahir di lingkungan masyarakat multikultural. Rasulullah Saw sendiri dalam menjalankan misi dakwahnya, bersentuhan dengan budaya masyarakat Mekkah yang plural saat itu. Terdapat beberapa keyakinan yang telah tumbuh sebelumnya seperti Nasrani, Yahudi, Majusi dan Paganisme ${ }^{13}$. Islam disebarkan dengan merangkul bukan memukul. Islam disampakan dengan mengajak bukan menghujat. Ajaran Islam menjadi titik temu, bukan titik tengkar dalam kehidupan berbangsa dan bernegara. Singkatnya, agama Islam adalah sebuah ajaran yang menjunjung tinggi nilai- nilai kemanusiaan ${ }^{14}$. (Azra, 2002:15).

Islam sangat menghargai keragaman dan moderasi. Dalam pandangan Islam keragaman merupakan sebuah keniscayaan (sunnatullah) yang harus kita jalankan. Keragaman adalah kehendak Allah Swt melalui penciptaan-Nya. Mengingkari keragaman sama saja dengan mengingkari terhadap ciptaan Allah SWT. Pondok pesantren sebagai lembaga pendidikan dengan doktrin Ahlussunnah Waljamaah an-Nahdliyah-nya dalam menyikapi perkembangan baru selalu dilakukan dengan cara dialogis-kritis dan bertanggung jawab, seperti bahsul masail halaqah dan lain sebagainya, berdasarkan standar metodologi kajian keilmuan. Proses ini telah menjadikan penerimaan pesantren terhadap miltikulturalisme lebih terbuka namun tetap kritis.

\section{F. Simpulan}

Dari Pembahasan hasil penelitian di atas, kemudian didiskusikan dengan beberapa teori yang ada, dapat disimpulkan bahwa model pendidikan di Ma'had Aly PPSS telah menerapkan nilai-nilai pendidikan multikultural yang dapat membangun paham moderasi sebagai cunter naratif terhadap

12 Donna M. Gollnick, \& Chinn, P. C. Multicultural Education in a Pluralistic Society (second ed.). (Columbus: Charles E. Merrill Publishing Company, 2011), 209.

13 Hamid Al-Husaini, Riwayat Hidup Nabi Besar Muhammad SAW, (Jakarta : Waqfiyah Al-Hamid Al-Husaini Press, 1990), 44.

14 Azyumardi, A. Paradigma Baru Pendidikan Nasional: Rekonstruksi Dan Demokratisasi, (Jakarta: Penerbit Buku Kompas, 2002), 15.

$292 \mid$ JURNAL LISAN AL-HAL 
ancaman paham radikalisme yang berkembang akhir-akhir ini. Penerapan pendidikan multikultural tersebut dilakukan dengan dua pola, yaitu : (1). Melalui proses internalisasi nilai; proses internalisasi ini terdiri dari dua tahap: pertama tahap penambahan dengan tiga prinsip utama yaitu : pengembangan, perbaikan dan penyaringan; kedua adalah level perubahan, yakni pemahaman terhadap dimensi multikulturalisme dilakukakan melalui proses dialogis-metodelogis (2). Pola transformasi nilai, penguatan paham moderasi melaluli proses transformasi nilai pendidikan multikultural, dilakukan melalui lima dimensi, yaitu : (a). Conten Integration (integrasi budaya); (b). The Knowladge Construction Process (Konstruksi budaya dalam pengetahuan); (c). An equality of Pedagogment (tahap metode pembelajaran); (d). Culturally Sensitive Teaching Strategies (tahap interaksi dalam pengajaran); dan (e). Prejudice Reduction in Instructional;

\section{DAFTAR PUSTAKA}

Ainurrofiq, D. "Emoh" Sekolah Menolak "Komersialisasi Pendidikan" dan "Kanibalisme Intelektual", Menuju Pendidikan Multikultural, Yogyakarta: INSPEAL Press, 2003.

Al-Husaini, H.M.H Al-Hamid, Riwayat Hidup Nabi Besar Muhammad SAW, Jakarta : Waqfiyah Al-Hamid Al-Husaini Press, 1990.

Azyumardi, A. Paradigma Baru Pendidikan Nasional: Rekonstruksi Dan Demokratisasi, Jakarta: Penerbit Buku Kompas, 2002.

Banks, J.A. An introduction to Multicultural Education, Boston-London: Allyn and Bacon Press, 2004.

Educating Citizens In Multicultural Society. Second edition. New York: Teachers College Columbia University. 2007.

Gollnick, D. M., \& Chinn, P. C. Multicultural Education in a Pluralistic Society (second ed.). Columbus: Charles E. Merrill Publishing Company, 1986.

Howard, Karen, The Emergences of Children's Multicultural Sensitivity: An Elementary School Music Cultural Project, Journal of Research Music Education (2018), Vol. 66(3).

Iqbal, Abu Muhammad, Pemikiran Pendidikan Islam : Gagasan-gaasan Besar Para Ilmuan Muslim, Yogyakarta: Pustaka Pelajar, 2015.

Madjid, Nurcholish, Bilik-Bilik Pesantren: Sebuah Potret Perjalanan, Jakarta: Paramadina, 1997.

Mahfud, C. Pendidikan Multikultura. Yogyakarta: Pustaka Belajar, 2009.

Mastuhu. Dinamika Sistem Pendidikan Pesanantren, Suatu Kajian tentang Unsur dan Nilai Sistem Pendidikan Pesantren, Jakarta: INIS, 1994.

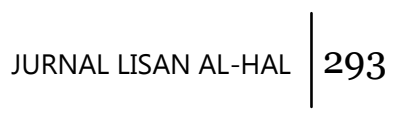


Maursy, Muhammad Munir, al-Tarbiyah al-Islamiyah : Ushuluha wa Tahawwuruha fi Bilal al-Arabiyat, Kairo: A'lam a-Kutub. 1977.

Milles, Matthew B. and A. Michael Huberman, Analisis Data Kualitatif, terj.Tjetjep Rohendi Rohidi, Jakarta : UI-Press, 1992.

Moleong, L.J. (Metodologi Kualitatif Edisi Revisi, Bandung: PT. Remaja Rosdakarya, 2005.

Muhajir, Noeng, Metodologi Keilmuan : Paradigma Kualitatif, Kuantitatif dan Mixed, Yogyakarta : Rake Sarisan, 2007.

Parekh, B. Rethinking Multiculturalism: Cultural Diversity and Political Theory. New York: Palgrave Macmillan, 2006.

Satori, A. dan Subhan, A. "Kepemimpinan Masyarakat Majemuk (Studi Model Kewenangan, Pembagian Peran, dan relasi Kuasa Pemimpin Tradisional di Dusun Susuru, Panawangan, Ciamis", Proceeding, Seminar Nasional Dies Natalis FISIP Unsoed tahun 2014.

Sugiyono. Metode Penelitian Kuantitatif, Bandung: Alfabeta, 2006.

Tilaar, H.A.R. Perubahan Sosial dan Pendidikan: Pengantar Pedagogik Transformatif untuk Indonesia, Jakarta: Grasindo, 2004.

Wahid, A. Gusdur, Menjawab Kegelisahan Rakyat, Jakarta: Penerbit Buku Kompas, 2007.

Zakiyuddin, B. Pendidikan Agama Berwawasan Multikultural, Jakarta: Erlangga, 2005.

$294 \mid$ JURNAL LISAN AL-HAL 